\title{
Exploring the Impact of Technology Use with Cosmetic Science Guest-Speakers: A Qualitative Study
}

Gabriella Baki, PhD; Michael J. Peeters, PharmD, MEd

University of Toledo College of Pharmacy and Pharmaceutical Sciences

\begin{abstract}
Improvements in current classroom technology such as video conferencing have allowed geographically-distant guest-speakers to participate in teaching. However, is time and effort that faculty may spend coordinating guest-speakers helpful for their students' learning? Relevance is key to motivation and learning, and therefore, it would seem that professionals who can share industry applications and their experiences should help promote relevance. During the core application-based cosmetic science coursework in an undergraduate cosmetic science and formulation design degree at the University of Toledo, multiple industry experts come in as guest-speakers. The majority of them join remotely via a real-time video conferencing tool. The purpose of this study was to both explore the impact of guest-speakers on these students' learning, as well as to understand how guest-speakers might also value these experiences. Twenty-two students and sixteen guest-speakers participated. Using a qualitative approach, authors used an inductive thematic analysis of transcripts from focus-groups of students and interviews of guest-speakers. Twenty-one codes were identified, and five themes were constructed for both the student and guest-speaker groups. Themes from both groups were integrated and distilled into an essence related to teaching and learning. Our results indicated that students greatly appreciated the relevance from guest-speakers to augment their introductory/foundational instruction from faculty. From guest-speakers' perspectives, teaching students was formative towards developing informed future coworkers for the cosmetic industry. Technology enabled much of this. Overall, we believe that professional, experienced guest-speakers can make an impact on students. We hope that other higher education institutions might consider technology to foster use of guest-speakers within their programs.
\end{abstract}

Keywords: guest-speaking, qualitative, teaching, learning, cosmetic science, technology

\section{Introduction}

Relevance can be an important contributor to students' learning through increasing students' motivation. ${ }^{1-2} \mathrm{~A}$ number of theories to learning invoke relevance as a vital contributor, including Relevance Theory, ${ }^{3}$ Self-Determination Theory, ${ }^{4}$ Social Learning Theory, ${ }^{5}$ and others. ${ }^{6}$ Guest-speakers may play an important role in students' educational experiences. ${ }^{7}$ Multiple studies in diverse areas such as criminal justice, ${ }^{8}$ accounting, ${ }^{9}$ communication, ${ }^{10}$ and supply-chain management ${ }^{11}$ have all reported learning benefits from using guest-speakers. By exposing students to real-life experiences and providing insights into a particular field, guest speakers may promote student engagement and allow students to better appreciate the relevance of course content. While integrating guest-speakers or industrial professionals into classroom discussion may be practiced among some graduate pharmaceutical sciences and cosmetic science programs, evidence for use of guest-speakers in undergraduate-level pharmaceutical science coursework in the United States is lacking.

Technology may be able to help. Use of technology to support traditional face-to-face instruction in higher education is expanding. ${ }^{12}$ Institutions are investing in classroom technology, such as lecture-capture software, that allows students to learn

Corresponding author: Gabriella Baki, PhD

University of Toledo

College of Pharmacy and Pharmaceutical Sciences

Toledo, OH; Email: Gabriella.Baki@utoledo.edu difficult concepts at their own pace, not limited by time, place or space. ${ }^{13}$ Similarly, improved video-conferencing technology makes webinar-style lectures more available to classroom instructors, which could allow integration of geographicallydistant speakers into their classrooms. While technology that supplements face-to-face instruction has received more attention in the last few years for collaborating with colleagues in higher education, ${ }^{14-15}$ evidence is lacking on use of guestspeakers via this technology. The College of Pharmacy and Pharmaceutical Sciences at the University of Toledo uses guestspeakers in four core lecture-based courses within our Bachelor of Science in Pharmaceutical Sciences (BSPS) Cosmetic Science and Formulation Design Program. Thus, the innovation in this report is using technology to meaningfully integrate cosmetic science industry guest-speakers into an undergraduate program.

The cosmetic industry is a trend-driven sector, where changes occur frequently due to ever-changing expectations of consumers. Being aware of changes and becoming familiar with the regulatory environment, main consumer concerns, and leading trends is important for students to make themselves competitive and market-ready. It was reported in other fields ${ }^{8-11}$ that lectures by guest-speakers are able to bring the field to the classroom and open students' minds to different viewpoints. We hope this is similarly effective for cosmetic science education.

The objective of this qualitative research study was to better understand and systematically describe students' and speakers' experiences with guest lectures within undergraduate cosmetic science coursework. We aimed to explore the experiences of 
students' learning in guest lectures and to understand guestspeakers' perceptions of those lecturing experiences.

\section{Methods}

Qualitative methods explore how some human-beings experience a phenomenon; it is about understanding the essence of an experience about that phenomenon. ${ }^{16-17}$ Qualitative methods allow researchers to put themselves in another person's shoes and to understand the subjective experiences of participants. ${ }^{16}$ This qualitative study was approved as exempt by the Social and Behavioral Institutional Review Board at the University of Toledo. All participants (students and guest-speakers) provided informed consent for this investigation.

Context. The BSPS Cosmetic Science and Formulation Design program at the University of Toledo College of Pharmacy and Pharmaceutical Sciences, requires all majoring students to take three lecture-based core courses: "Cosmetic Raw Materials," "Cosmetic Science 1," and "Cosmetic Science 2." While this article is focused on these three core courses, another article details the entire curriculum for this BSPS major in Cosmetic Science and Formulation Design. ${ }^{18}$

Each semester, guest lectures represent about $20 \%$ of lectures in each of these courses. The main faculty (GB) for this coursework regularly invites industry speakers into all three of these lecture-based core courses based on their expertise. As experts from the cosmetic and personal care industry, many invited speakers currently hold senior positions in their companies. Speakers may travel to campus and give their lecture(s) in-person, but the majority (approximately 78\%) deliver their lectures synchronously online using a web-based conferencing tool.

For most course topics, the faculty presented the basic concepts, definitions and important terminology and then invited a guest-speaker to enhance students' application of knowledge to industry. For example, one topic is skin-care products. In the classroom, the main faculty had lectures for students about skin-care products, including skin cleansers, moisturizers, anti-aging skin products, and anti-acne skin products. As a foundation, the faculty discussed goals of application, consumer needs, main ingredients, basic formulation technology, basic quality and performance testing, and packaging. At the end of these skin care lecture series, two industry guest-speakers discussed advanced imaging and measurement techniques for skin testing and claim substantiation, and they introduced students to clinical studies for a moisturizer product. Through these lectures from industry guest-speakers, students were exposed to advanced techniques and got an insight into the complexity of planning and completing studies on consumers.

This qualitative study focused on three courses taught to junior and senior cosmetic science students. As core courses for cosmetic science students, these three courses provide basic concepts that apply to many cosmetic industry career paths that students may choose following graduation. A fourth course, Introduction to Cosmetic Science, which also uses guest-speakers, is taught to students at all academic levels, and to multiple majors and colleges. We wanted to focus only on cosmetic science students because we considered these cosmetic science students as particularly suitable to examining our research question. This is because these students chose this major, with motivation and interest to positively frame these lectures, if these lectures are indeed helpful. Therefore, we excluded the "Introduction to Cosmetic Science" course from this study.

Technology. Guest lectures have usually been 45-55 min long, including time for questions and answers at the end of each presentation. Since geographical distance has been a barrier for the majority of industry guest-speakers used within our core cosmetic science lecture-based courses, most of the guestspeakers provided their lecture using a real-time video conferencing software, Blackboard Collaborate Ultra (Blackboard, Washington DC). As a trial session with each guestspeaker before the live lecture to ensure Blackboard Collaborate Ultra worked properly on both sides, the course faculty provided a link to the virtual classroom for each guestspeaker. This short session also gave an opportunity for the guest-speakers to familiarize themselves with this software. During the guest lecture, students were in a physical classroom and the course faculty connected the entire class with the guest-speaker via Blackboard Collaborate Ultra. An alternative option could be that each student uses their laptop from any location where they have a stable Internet connection, and logs in individually. Since the courses in our study were blended (partially online, though mostly in-class), students always came to the classroom. Lecture slides were uploaded into Blackboard Collaborate Ultra and were displayed on the screen during the guest lecture, along with a live video of the guest-speaker and class. A PDF copy of the lecture slides was also uploaded to Blackboard to the specific course before the lecture, allowing students to download and/or print the slides and take notes during each guest lecture.

At the beginning of each guest lecture the faculty gave the students a worksheet, called " 13 facts I learned today from the guest-speaker." Students could earn a bonus point by writing down thirteen facts they learned during the guest lecture and turning in the worksheet to the faculty for grading at the end of class. After grading, the worksheet was given back to the students to use it to study for quizzes and exams.

Participants \& Data Collection. Within this investigation, both students and guest-speakers participated in sharing their experiences. The program director and course faculty conducted all interview and focus-group sessions with all participants. Iteratively, data were collected from participants in both groups until a saturation of coding was found for each 
group. ${ }^{19}$ We deemed saturation when no new codes were identified from new focus-group or interview transcripts.

Focus-groups. Focus-groups consisted of 4-6 students. To be eligible to participate, students had to complete at least two of the three courses. All eligible students were invited. Students were guided to reflect on their own experience. Focus-groups allowed students to build from one another in the answers they provided. $^{20}$ These focus-groups were semi-structured. The interviewer asked a series of open-ended questions (see Table 1) of students with other follow-up questions as needed. Using either a conference room or small classroom, each student focus-group session took approximately 30 minutes. Each focus-group session was audio-recorded and later transcribed.
Interviews. The Cosmetic Science and Formulation Design program has industry speakers from a variety of fields, including ingredient manufacturing, research and development, formulation, testing (including quality control, sensory testing and performance testing), regulations, as well as technical marketing. One-by-one, guest-speakers were interviewed over the phone due to busyness of the guest-speakers and because they were geographically distant from each other and also from the faculty. Similar to focus-groups, a semi-structured style of interview was employed, with major question threads in Table 1 for these interviews. Each phone interview took approximately 15 minutes. Sessions were audio-recorded and later transcribed.

Table 1. Questions* for students and guest-speakers

\begin{tabular}{|c|c|}
\hline Focus-group questions for Students & Interview questions for Speakers \\
\hline $\begin{array}{l}\text { 1. Within your PHPR 3040-Cosmetic Raw Materials, } \\
\text { PHPR 4730-Cosmetic Science 1, or PHPR 4750- } \\
\text { Cosmetic Science } 2 \text { courses, have you appreciated } \\
\text { speakers coming to the class and providing } \\
\text { lectures? Tell me more-why or why not? }\end{array}$ & $\begin{array}{l}\text { 1. Why did you decide to accept my invitation and } \\
\text { provide your lecture(s) for cosmetic science } \\
\text { students in our undergraduate program? } \\
\text { 2. What was your experience with this? Is this or } \\
\text { another avenue preferred to provide your lecture? }\end{array}$ \\
\hline $\begin{array}{l}\text { 2. What was the most interesting lecture you heard } \\
\text { from our speakers so far? Why? What was the } \\
\text { least interesting lecture? Why? }\end{array}$ & $\begin{array}{l}\text { 3. What drawbacks have you experienced when you } \\
\text { provided your lecture in our class? What other } \\
\text { drawbacks might you envision with this }\end{array}$ \\
\hline $\begin{array}{l}\text { 3. Beyond teaching lecture content, what other } \\
\text { benefits do you think guest lectures offer to you (if } \\
\text { any)? }\end{array}$ & $\begin{array}{l}\text { technology-based approach? } \\
\text { 4. Do you lecture in any other bachelor programs in } \\
\text { the United States? Do you know of any other }\end{array}$ \\
\hline $\begin{array}{l}\text { 4. What do you think about this way of delivering } \\
\text { lectures? Many times, the low-tech option would } \\
\text { be to not have guest-speakers (because of travel } \\
\text { and other associated costs), what is your } \\
\text { preference-speakers via technology or no guest- } \\
\text { speakers? }\end{array}$ & $\begin{array}{l}\text { schools that use guest-speakers for teaching } \\
\text { purposes? Please share your experience(s). If you } \\
\text { do not know any other schools, or do not teach in } \\
\text { any other programs, why do you think this is the } \\
\text { case? }\end{array}$ \\
\hline $\begin{array}{l}\text { 5. Please share any drawbacks that you have } \\
\text { experienced when we have had a guest-speaker in } \\
\text { our class. }\end{array}$ & \\
\hline
\end{tabular}

*Note: Focus-groups and interviews were semi-structured. Above is the structure template of questions, however in each specific situation, the interviewer may have probed further based on specific responses from participants.

Data Validation Strategies. Creswell suggests for trustworthiness and thoroughness that at least two validation strategies be used during any qualitative investigation. ${ }^{17}$ In this study, we employed three key validation strategies of triangulation, member checking and rich, thick description. Triangulation is about trustworthiness (validity) and refers to the careful evaluation and review of the data collected in order to establish validity in the findings along with constructing themes. ${ }^{17}$ In this study, our investigator triangulation was from two investigators involved in coding to minimize bias; our method triangulation came from data collected from two different sources-focus-groups and interviews-comparing student perspectives with guest-speaker perspectives. Member-checking is used to assure accuracy and establish authenticity and credibility (reliability, consistency) of a qualitative study. ${ }^{17}$ In this study, the transcripts were sent back to the participants (students and guest-speakers), wherein participants confirmed accuracy of the transcripts. Rich, thick description is about thoroughness, transferability and transparency. It refers to providing a detailed description of the study that could enable a reader to transfer findings to other settings if they choose to. ${ }^{17}$ In this study, we provided examples for codes. Additionally, we explained how the codes were constructed from the themes, with themes from both focus 
groups and interviews distilled into an essence. We provided concept maps to transparently illustrate this process.

Data analysis. We employed an inductive coding strategy for qualitative text analysis. ${ }^{21}$ To strengthen the trustworthiness of the results, two individuals (GB, MJP) coded the data and then assessed inter-rater agreement using Cohen's kappa (i.e., investigator triangulation). We followed Interpretation of Cohen's kappa scores by Landis \& Koch. ${ }^{22}$ Our analytic strategy consisted of each investigator independently first reading all the transcripts, followed by open-coding of the transcripts using as many codes as ideas communicated by the students and guest-speakers. ${ }^{23}$ After the initial open-coding and interrater agreement assessed, we iteratively refined the codes through discussions between the two coders. From these refined codes, both investigators together constructed larger themes, ${ }^{17,21}$ with all codes and themes placed into concept maps for visual analysis. ATLAS.ti computer software (version 8.2.4, $\mathrm{GmbH}$, Berlin, Germany) was used in qualitative coding and analysis, while the CmapTools software (version 6.03,
Institute for Human and Machine Cognition, Pensacola, FL) was used for concept maps. Herein, we chose a digital approach to concept mapping ${ }^{24}$ so that we could easily, cleanly, and transparently illustrate how we transitioned from our codes to our themes to our essence. In the last step, the themes were integrated into an essence of the experience for the participants. The essence refers to the essential meaning of the phenomenon and focuses on the common experiences of the participants; it helps the reader to understand what and how the phenomenon was experienced. ${ }^{17}$

\section{Results}

Student Codes. Twenty-four students were invited and twentytwo (92\% response rate) participated in one of five focusgroups. From inductive coding of transcripts, 21 codes were constructed for students. Examples of each code and the frequency of those codes are shown in Tables 2 and 3. Interrater agreement for students was considered substantial (kappa=0.75).

Table 2. Themes, codes, and examples for each code from student focus-groups

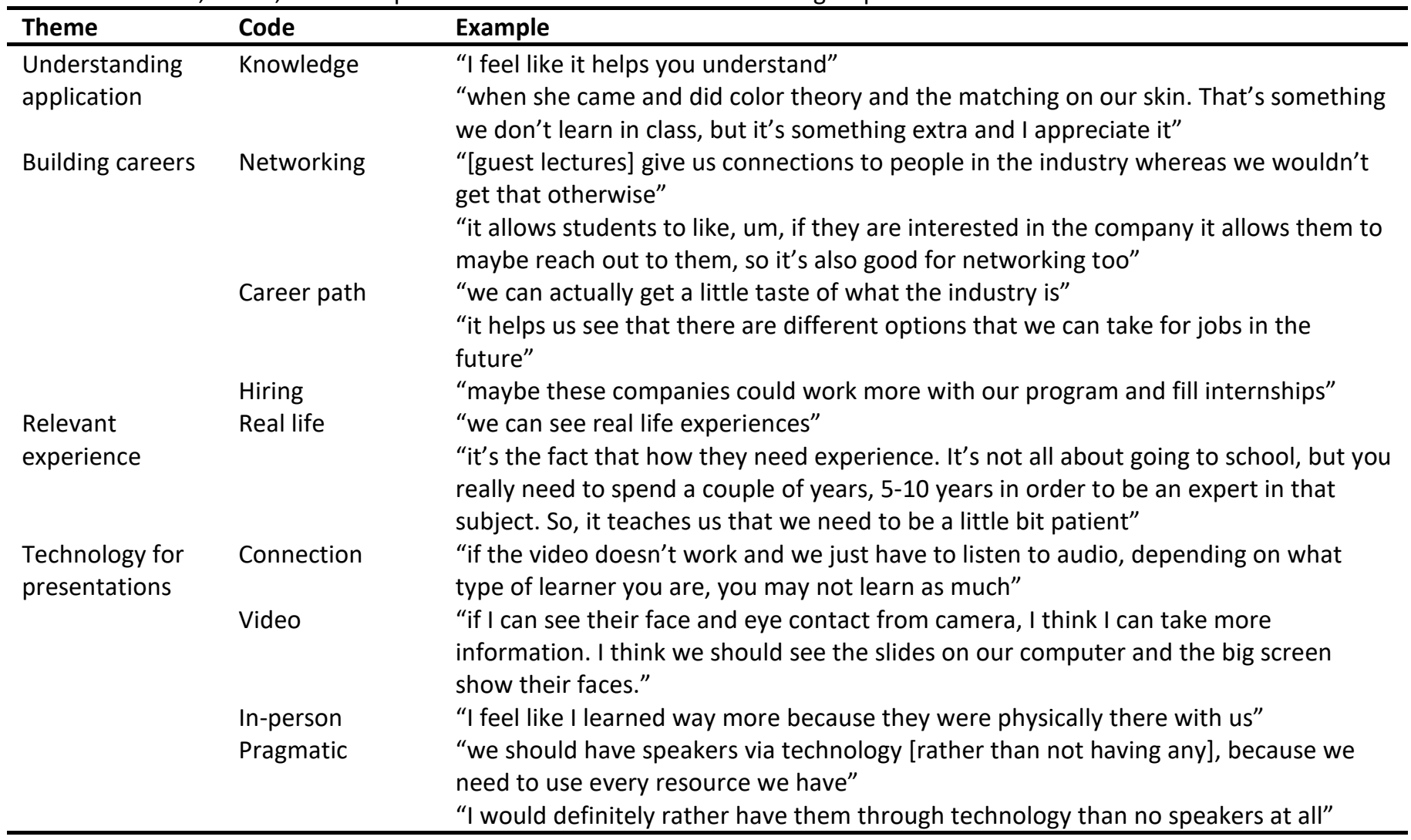


Table 3. 'Feedback from students' theme, codes, and examples for each code from student focus-groups

\begin{tabular}{|c|c|c|}
\hline Theme & Code & Example \\
\hline \multirow{11}{*}{$\begin{array}{l}\text { Feedback from } \\
\text { students }\end{array}$} & Engaging & "they were both very engaging" \\
\hline & Hands-on & $\begin{array}{l}\text { "I liked hers a lot because it was hands on and she actually had us practice doing color } \\
\text { theory and everything which was cool" }\end{array}$ \\
\hline & & "she had a bunch of stuff we could actually touch and interact with" \\
\hline & 13 facts & $\begin{array}{l}\text { "I really enjoy how you give us those worksheets before the lecture therefore it helps } \\
\text { to focus and write down any notes we have'" }\end{array}$ \\
\hline & Distinctive & $\begin{array}{l}\text { "it was really cool because they somehow know what the trends are going to be five } \\
\text { years in the future" }\end{array}$ \\
\hline & & $\begin{array}{l}\text { "I really like hers because it was kind of cool, even as a consumer to see what your } \\
\text { color and undertone is" }\end{array}$ \\
\hline & Building & $\begin{array}{l}\text { "I like [having guest-speakers] toward the end [of a topic] because I feel like we } \\
\text { already kind of know and we know more terminology" }\end{array}$ \\
\hline & $\begin{array}{l}\text { Quality } \\
\text { improvement }\end{array}$ & "having an anonymous survey would be beneficial" \\
\hline & Disorganized & $\begin{array}{l}\text { "the slides are kind of say bland. They weren't very eye catching [...] no organization" } \\
\text { "it was a very disorganized lecture and it just wasn't presented in a very eased way. It } \\
\text { was just more of all over the place, it didn't flow well" }\end{array}$ \\
\hline & Overwhelming & "there was just a lot of information on every single slide and there were no tables" \\
\hline & $\begin{array}{l}\text { No personal } \\
\text { interest }\end{array}$ & $\begin{array}{l}\text { "that was probably one of the boring ones just because I'm not interested in that } \\
\text { [topic]" }\end{array}$ \\
\hline
\end{tabular}

Themes Constructed from Codes. Coding from students were built into five themes. Students emphasized that having guestspeakers notably improved their learning experiences. Guestspeakers helped them understand the application of their knowledge via practical examples. Additionally, guest lectures provided opportunities for students to start building their career while in school via insight into various career paths, and networking with speakers from various fields. Considering the use of technology for delivering lectures, all students agreed that they prefer in-person instruction, because it can be more engaging, and in-person lectures often have hands-on parts when students can smell and look at various ingredients/products provided by the speaker. However, they noted that they understood that it was not feasible for many speakers to come to campus for a single lecture. All students agreed that they would rather have guest-speakers via technology than not having any industry speakers in their courses. Focus-groups also provided many advantages of having guest-speakers, such as how guest-speakers build on base instruction with applications, and how guest-speakers provide some very unique ("cool") experiences via their presentations. Negative, critical feedback was also very helpful and will be used to improve the lecture and experience in the future. Figure 1 illustrates a concept map of theses codes and themes from students. 
Figure 1. Coding to themes from students

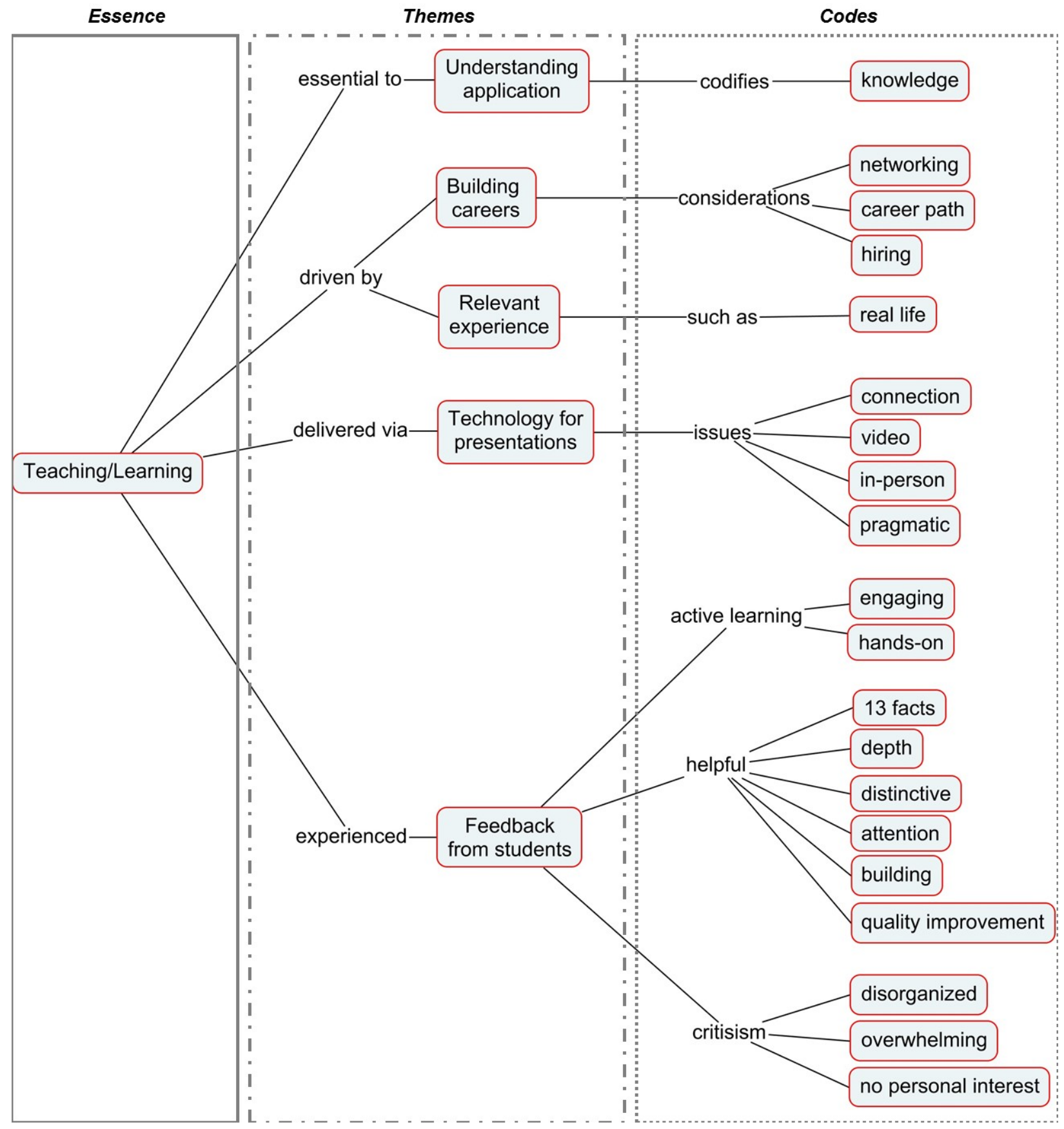

Guest-Speaker Codes. Twenty-two guest-speakers were invited and sixteen (70\%) were independently interviewed. From inductive coding of transcripts, 21 codes were identified.
Examples of each code and the frequency of those codes are in Tables 4 and 5. Similar to students, inter-rater agreement of coding for transcripts from guest-speakers was considered substantial as well (kappa=0.67). 
Table 4. Themes, codes, and examples for each code from guest-speaker interviews

\begin{tabular}{|c|c|c|}
\hline Theme & Code & Example \\
\hline $\begin{array}{l}\text { Subject matter } \\
\text { expert } \\
\text { perspectives }\end{array}$ & Instruction & $\begin{array}{l}\text { "I really enjoy speaking about cosmetic science, specifically in my area of } \\
\text { expertise" } \\
\text { "I truly believe that knowledge is not only gained by reading and working, but } \\
\text { most effective way of learning is by sharing knowledge" }\end{array}$ \\
\hline \multirow[t]{6}{*}{ Career guidance } & Mentoring & $\begin{array}{l}\text { "I have been most fortunate to have had a handful of mentors that guided me } \\
\text { through my career choices. I feel a strong obligation to be a mentor in any way I } \\
\text { can." } \\
\text { "I think it's important to reach out, educate and mentor younger people to } \\
\text { create the next generation of cosmetic chemists." }\end{array}$ \\
\hline & Hiring & $\begin{array}{l}\text { "I'm in the business, I knew that when my company needed it would have a pool } \\
\text { of educated students to pull from for our employees or internships" }\end{array}$ \\
\hline & Career path & $\begin{array}{l}\text { "I think when you experience real world success stories, entrepreneurs, business } \\
\text { owners, then you can see others' path and viable directions that your career can } \\
\text { go in" } \\
\text { "it is really hard for people to understand what is going on in the industry and } \\
\text { especially in your field students are really eventually going to move to industry - } \\
\text { the cosmetic business" } \\
\text { "It's important for me to share my experiences with the students and help them } \\
\text { understand what great opportunities there are within the cosmetic sciences." }\end{array}$ \\
\hline & Partnership & $\begin{array}{l}\text { "my colleague has been making a significant effort to connect our company with } \\
\text { universities" }\end{array}$ \\
\hline & Networking & $\begin{array}{l}\text { "they [students] have the opportunity to network and ask questions that they } \\
\text { may not ask otherwise" }\end{array}$ \\
\hline & Giving back & $\begin{array}{l}\text { "I want to support such a program in any way I can and one of those ways could } \\
\text { be through guest lecturing" } \\
\text { "I accepted the invitation to lecture to the cosmetic science students because I } \\
\text { was one once. I know exactly what they were taught and what valuable } \\
\text { information about [topic] could help them as formulators or research scientist in } \\
\text { their future" }\end{array}$ \\
\hline \multirow[t]{6}{*}{$\begin{array}{l}\text { Relevant } \\
\text { experience }\end{array}$} & Grad program & $\begin{array}{l}\text { "I do not lecture at any other bachelor programs. Fairleigh Dickinson uses guest } \\
\text { lecturers in their Master's program" }\end{array}$ \\
\hline & & "We have also done lectures for graduate students at Long Island University." \\
\hline & Unique & $\begin{array}{l}\text { "this was the first program that I heard of that actually focused on cosmetic } \\
\text { science and cosmetic formulation" }\end{array}$ \\
\hline & & $\begin{array}{l}\text { "Participation in your program is a unique experience for me. UT College of } \\
\text { Pharmacy and Pharmaceutical Sciences is my only experience with } \\
\text { undergraduate education." }\end{array}$ \\
\hline & Experience & $\begin{array}{l}\text { "Having experience in industry, I know that dissemination of knowledge is key to } \\
\text { success" }\end{array}$ \\
\hline & & $\begin{array}{l}\text { "motivated me to give talks and speeches to upcoming young scientists who can } \\
\text { benefit from my years of experience" }\end{array}$ \\
\hline
\end{tabular}


Table 5. Further themes, codes, and examples for each code from guest-speaker interviews

\begin{tabular}{|c|c|c|}
\hline Theme & Code & Example \\
\hline \multirow[t]{8}{*}{$\begin{array}{l}\text { Technology for } \\
\text { presentations }\end{array}$} & $\begin{array}{l}\text { Current/ Distance } \\
\text { Learning }\end{array}$ & $\begin{array}{l}\text { "In the day and age of working remotely, using technology is critical to being able } \\
\text { to work with different people. I do it on a daily basis, providing multiple } \\
\text { presentations online" } \\
\text { "As technology has advanced over the years and become more interactive, I } \\
\text { think students are more and more comfortable with the online format and this } \\
\text { experience was fine for me as a presenter." }\end{array}$ \\
\hline & Pragmatic & $\begin{array}{l}\text { "Recognizing the distance and travel limitations, I was glad to have the ability to } \\
\text { present the lecture online" } \\
\text { "Lecturing online is easy and excellent" }\end{array}$ \\
\hline & Reactions & $\begin{array}{l}\text { "One drawback is that it was challenging to relate to the students when I was } \\
\text { giving the lectures. It's not the same as being there in person where I can better } \\
\text { engage the students and see their reactions." } \\
\text { "You are disconnected with your audience; you cannot look out and see if you } \\
\text { are connecting with them or have lost them. This is the biggest drawback" }\end{array}$ \\
\hline & Connection & $\begin{array}{l}\text { "The main drawback from a technical side is the fact that our [company's] } \\
\text { security settings did not want to allow us to run the app for the presentation. } \\
\text { We had to have our IT team grant access to the software. But we were prepared } \\
\text { ahead of time, so it did not cause an issue." } \\
\text { "The only drawback we experienced was opening the site and getting an initial } \\
\text { connection. Once that was figured out, the remainder of the lecture went } \\
\text { smoothly." }\end{array}$ \\
\hline & Presenter & "My PowerPoint presentation had transitions and dropdowns, however, when I \\
\hline & Freedom & $\begin{array}{l}\text { gave the presentation online, the whole slide appeared at once. I would have } \\
\text { liked the opportunity to present it the way I put it together." } \\
\text { "The only drawback I experienced was the fact that I was not able to connect my } \\
\text { own laptop." [this speaker presented in person] }\end{array}$ \\
\hline & Audio & $\begin{array}{l}\text { "one drawback was the audio quality, especially when the students were asking } \\
\text { questions" } \\
\text { "When there is poor audio the lecture is almost pointless because the student } \\
\text { can hardly understand or pay attention. It can also be frustrating for the } \\
\text { speaker." }\end{array}$ \\
\hline & Video & $\begin{array}{l}\text { "I prefer teaching the class in person [...] but not the webinar kind where I don't } \\
\text { even see the faces of my students" }\end{array}$ \\
\hline \multirow[t]{4}{*}{$\begin{array}{l}\text { Feedback from } \\
\text { speakers }\end{array}$} & Interdisciplinary & $\begin{array}{l}\text { "Different people in industry have different experience and educations. The } \\
\text { formulation specialists should know something about the biology and clinical } \\
\text { aspects of their product's performance." }\end{array}$ \\
\hline & Piloting & $\begin{array}{l}\text { "I believe that it is beneficial to have some experience and familiarity with this } \\
\text { technology [online platform used for the guest lectures]" }\end{array}$ \\
\hline & $\begin{array}{l}\text { Quality } \\
\text { improvement }\end{array}$ & $\begin{array}{l}\text { "I'm always open to suggestions if they need any improvement or whether I was } \\
\text { going fast. That kind of feedback I would also like too" }\end{array}$ \\
\hline & Occurrence & "The only drawback is that is a one-time event" \\
\hline
\end{tabular}

Themes Constructed from Codes. Coding from guest-speakers were constructed into five themes. Many guest-speakers affirmed that they were subject-matter experts in this field, and that they enjoyed teaching and sharing their knowledge with students. Numerous speakers expressed their motivation for providing career guidance for students, including mentoring. Additionally, many speakers noted that sharing their experience motivated them, and they understood how essential it can be as part of students' education. None of the speakers heard about or taught in any other undergraduate cosmetic science-focused program at the time of their interview, and they noted that participating in our program was a unique experience for them. Multiple technology-related suggestions were identified, which will help the faculty improve the experience for the future. Figure 2 shows a concept map of codes and themes from these guest-speakers. 
Figure 2. Coding to themes from speakers

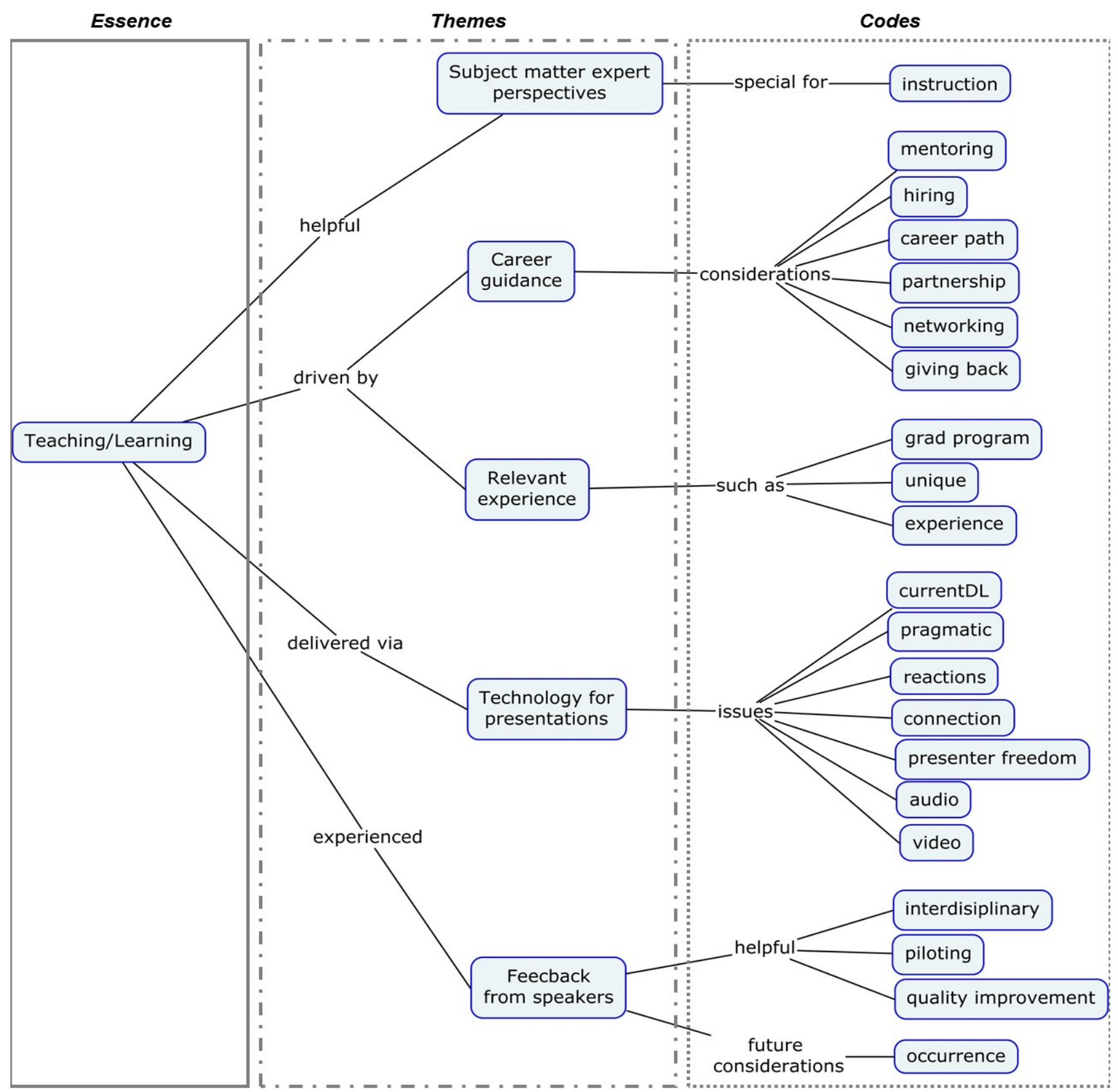

Essence Distilled from Themes. Between the concept maps (Figures 1 and 2), there was considerable overlap in themes. The essence of experiences from both students' and guestspeakers' perspectives illuminated different sides of the same coin (i.e., teaching and learning). These students highly valued learning from the guest-lecturers, while these guest-speakers highly valued teaching these students (and so these focusgroups and interviews data collection methods triangulated in support of one another). One example was when students said the lectures by industry guest-speakers provided them with an opportunity to obtain insights into different types of careers ("it helps us see that there are different options that we can take for jobs in the future"), while speakers acknowledged that it is hard for students to understand how the industry works and what opportunities are available in the industry, but the guest lectures may help with this ("It's important for me to share my experiences with the students and help them understand what great opportunities there are within the cosmetic sciences"). Another example was when the students suggested that an anonymous survey could be used at the end of each guest lecture so the students could provide feedback to the speaker ("having an anonymous survey would be beneficial"), and some 
speakers also mentioned that having more feedback would be helpful so they could improve their lecture-style or adjust content if needed ("I'm always open to suggestions if they need any improvement or whether I was going fast. That kind of feedback I would also like too"). Thus, the essence of this Teaching and Learning had two perspectives; from the students' perspective, it was that students greatly appreciated learning relevance from guest-speakers to support the introductory/foundational instruction from faculty. From a guest-speaker perspective, teaching students was formative towards developing future informed colleagues for the cosmetic industry.

\section{Discussion}

In this study, we set out to explore the nature of students' learning from guest-speakers, including both face-to-face learning and learning via web-conferencing software. Our results shed light on how teaching by guest-speakers helped students learn the lecture material, and why these students appreciated having guest-speakers in three of their lecturebased cosmetic-science courses. Additionally, we now better understand how speakers may benefit from these guest lectures.

Multiple theories of learning relate to relevance (as discussed earlier), wherein relevance is key to motivation and learning. ${ }^{3-6}$ Thus, professionals in related careers, who can share industry applications based upon their insights and experience, can help foster relevance. ${ }^{8-11}$ In accordance with these literature findings, this study indicated that from students' perspectives, guest-speakers made the lecture material more relevant and complete, by presenting current examples, ideas and challenges. For example, faculty introduced and discussed consumers' fears and scientific evidence regarding the use of sulfates in skin cleansers with students. Then, a guest-speaker presented a case study in which he explained various ways for substituting sulfates in cleansers and the challenges of such a task. This example allowed students to recognize how trends discussed by faculty were handled within a company. Additionally, the various speakers' interactions provided students with concrete examples of careers in this field.

As discussed above, there was considerable overlap in themes between the two groups. The essence from both students' and guest-speakers' perspectives focused on Teaching and Learning. While these terms each represented different perspectives, both students and speakers highly-valued interacting with one another. Thus, this investigation characterized a win-win situation. Students won with their learning. Guest-speakers won with teaching relevant aspects from their unique cosmetic industry perspectives (i.e., the reward of contributing their industry-knowledge and experience for the future industry workforce). We confirmed insights from other disciplines that guest-speakers integrated real-world, practical perspectives with fundamentals of coursework. $^{8-11}$ While academics can be derided for their "ivory-tower" perspectives, ${ }^{25}$ guest-speakers can help show students current changes in the industry, with consequences of those changes, as well as what those changes could mean for future cosmetic-industry business. Every guest-speaker was excited to be able to teach these undergraduate students. Notably, many guest-speakers believed it was a great mentoring opportunity for them, in addition to being able to share their knowledge and experience with future cosmetic scientists.

An innovative approach we used in this study was to use technology to facilitate engagement by guest-speakers when they were unable to travel to campus. While both students and speakers indicated they prefer in-person lectures, they both agreed that in today's technology-driven world, using online software (Blackboard Collaborate Ultra in our study) was quite easy, connected students with geographically-diverse experts, and was also more convenient than travel to fit this into their busy schedule for some regionally-located guest-speakers. Some technology-related issues were identified by both students and speakers, and these minor issues will be fixed for future course iterations. An example of such an issue was a speaker's poor audio connection, which made it difficult for students to focus on the lecture content and follow the speaker. As mentioned above, the faculty worked with each guestspeaker before their presentation to make sure they were familiar with the software (though also to test whether the Internet connection and equipment worked properly). In this one case, the "quick fix" was for the faculty to call the guestspeaker on their cellphones and put the guest-speaker onto the faculty's cellphone speaker. This allowed for a better connection and made the lecture much more enjoyable. This situation underscored the importance of these equipment tests for future course iterations.

A notable limitation with having guest-speakers present online was a loss in face-to-face connection with students. This was mentioned in both student focus-groups and guest-speaker interviews. Having immediate feedback (reactions) from students can be helpful, such as non-verbal feedback from confused facial expressions. However, obtaining immediate feedback was challenging with video-conferencing lectures because a speaker at times could not see students' individual faces and reactions; speakers had difficulty in telling if, for instance, the speaker should repeat their explanation of a concept in different words. Similar to our own prior experiences collaborating with colleagues across the country, these cosmetic science students and guest-speakers agreed that audio with video was much preferred to audio alone.

Implications. This investigation explored undergraduate pharmaceutical sciences students' experience with guestspeakers. From this experience, an instructional model can be recommended for further consideration and investigation. This model attempts to maximize the relevance that guest-speakers can help create for the content by having faculty provide initial 
foundational instruction, and then facilitating guest-speakers to expand with their industry perspectives and applications.

The cosmetic industry has frequently changing trends and guidelines. A further implication with using guest-speakers is keeping this BSPS curriculum current. Being aware of changes and becoming familiar with the regulatory environment, main consumer concerns, and current trends is important for students to make themselves competitive and market-ready.

Limitations. As with other qualitative studies, we do not claim to generalize with our small sample from three courses at one university. Specific limitations within our investigative methods included scheduling interviews and facilitating focus-groups. Scheduling the one-on-one interviews with guest-speakers was challenging in many cases due to these guest-speakers' busy work schedules; there were multiple occasions when a phone interview had to be continued in email. One guest-speaker specifically asked if answering the interview questions via email was a possibility; it would allow them more time to think and reflect on their guest-lecturing experience. Because the interviewer was the course instructor and director of the program, this may have influenced students' feedback. Additionally, this was the first time that this faculty facilitated focus-groups. Learning from this experience, there are followup questions she could have asked in order to better probe further into certain parts of these experiences. This experience will undoubtedly improve her facilitating focus-groups in the future.

\section{Conclusion}

This qualitative study demonstrated that using guest-speakers in cosmetic science undergraduate courses made the lecture material more relevant and complete. This was irrespective of whether a guest-speaker was in-person or virtual. Webconferencing technology enabled geographically-distant speakers, who otherwise would not have been able to participate, to deliver their lecture without needing to travel (across country in some cases) to the University. Students felt guest-speakers (both in-person and virtual) helped students understand concepts from a different perspective and provided insight into various industry careers. From the guest-speakers' perspectives, these teaching opportunities allowed them to give-back by sharing their industry knowledge, as well as providing a helpful networking opportunity for and with these students that are intently interested in joining the cosmetic industry. Overall, we believe that professional, experienced guest-speakers can make an impact on students. We hope that other higher education institutions and programs (especially undergraduate programs) can use our experience as an idea to implement guest-speakers into their programs.
Author contributions: GB \& MJP conceived of this study. GB did the focus-group interviews with students, and phone interviews with guest-speakers. BG and MJP coded the transcripts, constructed the themes and essence. GB wrote the initial draft. MJP critically revised drafts of this manuscript. Both authors accept responsibility for this manuscript content.

Acknowledgements: The authors would like to express thanks to the students and guest-speakers for their time and participation in this research. Additionally, the authors would like to thank Jemila Council for transcribing the audio recordings, and Dr. Benjamin Aronson for his critical peerreview of a late manuscript version.

Conflicts of Interest: None

Funding/support: None

\section{References}

1. Albrich JR, Karabenick SA. Relevance for learning and motivation in education. J Exp Educ. 2018;86(1):1-10. doi: 10.1080/00220973.2017.1380593

2. Driscoll, MP. Motivation and Self-Regulation in Learning. In: Psychology of Learning for Instruction. 3rd ed., Boston MA; Pearson Education, Inc.; 2005.

3. Bandura, A. Social learning and personality development. New York: Holt, Rinehart and Winston; 1963.

4. Ryan RM, Deci EL. Self-determination theory and the facilitation of intrinsic motivation, social development, and well-being. Amer Psychol. 2000;55(1):68-78. doi: 10.1037110003-066X.55.1.68

5. Sperber D, Wilson D. Relevance: Communication and Cognition. 2nd Edition, Oxford/Cambridge UK: Blackwell Publishers; 1995.

6. Frymier $A B$, Houser ML. Does making content relevant make a difference in learning? Commun Res Rep. 1998;15(2):121-129. doi: 10.1080/08824099809362106

7. Mullins, PA. Using outside speakers in the classroom. APS Observer. 2001; 14(8). Available at https://www.psychologicalscience.org/teaching/tips/tips_ 1001.html. Accessed May 6, 2019.

8. Payne BK, Sumter M, Sun I. Bringing the field into the criminal justice classroom: Field trips, ride-alongs, and guest speakers. J Crim Just Educ. 2003;14(2):327-344. doi: 10.1080/10511250300085821

9. Metrejean C, Pittman J, Zarzeski MT. Guest speakers: Reflections on the role of accountants in the classroom. Account Educ. 2002;11(4):347-364. doi: 10.1080/0963928021000031466

10. Frymier AB, Shulman GM. "What's in it for me?": Increasing students' motivation. Commun Educ. 1995;44(1):40-50. doi: 10.1080/03634529509378996

11. van Hoek R, Godsell J, Harrson A. Embedding insights from industry in supply chain programmes: The role of guest lecturers. Supply Chain Manag Journal, 2011;16(2):142147. doi: $10.1108 / 13598541111115383$ 
12. Chen PD, Lambert AD, Guidry KR. Engaging online learners: the impact of web-based learning technology on college student engagement. Comput Educ. 2010;54(4):1222-1232.

13. Marchand JP, Pearson M, Albon SP. Student and faculty member perspectives on lecture capture in pharmacy education. Am J Pharm Educ. 2014;78(4):Article 74. doi: 10.5688/ajpe78474

14. Kiviniemi M. Effects of a blended learning approach on student outcomes in a graduate-level public health course. BMC Med Educ. 2014;14(47),1-7. doi:10.1186/1472-6920-14-47

15. Porter W, Graham C, Spring K, Welch K. Blended learning in higher education: institutional adoption and implementation. Comput Educ. 2014;75(3),185-195.

16. Creswell JW. Educational Research: Planning, conducting, and evaluating quantitative and qualitative research. $4^{\text {th }}$ ed. Boston MA: Pearson Education, Inc.; 2012.

17. Creswell JW. Qualitative Inquiry \& Research Design: Choosing Among Five Approaches. (3 ${ }^{\text {rd }}$ edition). Thousand Oaks, CA: SAGE Publications, Inc.; 2013.

18. Baki G, Borden MJ, Peeters MJ. Introducing an undergraduate degree of Cosmetic Science and Formulation Design within a College of Pharmacy. Inov Pharm. 2017;8(1):Article 9. doi: 10.24926/21550417.1308
19. Patton M. Qualitative research and evaluation methods. Thousand Oaks (CA): Sage Publications Ltd; 2002.

20. Rosenthal M, Qualitative research methods: Why, when, and how to conduct interviews and focus-groups in pharmacy research. Curr Pharm Teach Learn. 2016;8(4):509-516. doi: 10.1016/j.cptl.2016.03.021

21. Kuckartz U. Qualitative text analysis: a guide to methods, practice and using software. Thousand Oaks, CA: SAGE Publications, Inc; 2014.

22. Landis JR, Koch GG. The measurement of observer agreement for categorical data. Biometrics. 1977;33(1):159-174.

23. Castleberry A, Nolen A. Thematic Analysis of Qualitative Research Data: Is it as easy as it sounds? Curr Pharm Teach Learn. 2018;10(6):807-815. doi: 10.1016/j.cptl.2018.03.019

24. Brown D. Going digital and staying qualitative: Some alternative strategies for digitizing the qualitative research process. Forum Qual Soc Res. 2002; 3(2):Article 12.

25. Lewis LS. Scaling the Ivory Tower. Abingdon (UK): Routledge; 2018. 